\title{
ANALISIS KEUNTUNGAN USAHATANI BAWANG DAUN DI DESA BONGKUDAI UTARA KECAMATAN MOOAT KABUPATEN BOLAANG MONGONDOW TIMUR
}

\author{
Elsa Novera Mamusung \\ Leonardus Ricky Rengkung \\ Celcius Talumingan
}

\begin{abstract}
This study aims to analyze how much profit the farmers get in the activities of scallion farming in North Bongkudai Village, Mooat District, East Bolaang Mongondow Regency. The study was conducted for 3 months from October to December 2018. The data used in this study were primary data and secondary data. Primary data collection is through direct interviews with 60 respondents using the stratified random sampling method. Interviews were conducted based on a previously prepared questionnaire, and secondary data was obtained from the Bolaang Mongondow East Agriculture Office, North Bongkudai Village Office, Sam Ratulangi University Faculty of Agriculture Library, and Local Book Stores. The analysis in this study is qualitative and quantitative analysis presented in table form and then described descriptively. The results showed that the amount of profit of the scallion farmers per bed in Bongkudai Utara village in the first strata (lower layer) was Rp.426,664, while for the second strata (middle layer) was Rp.439,185 and for the third strata (upper layer) was Rp. 1,227,853. The highest profit of scallion farmers in Bongkudai Utara Village is in the third strata, reaching Rp1,227,853 per bed. ${ }^{* / r+p r m *}$
\end{abstract}

Keywords: revenue, cost, profit, North Bongkudai Village, East Bolaang Mongondow Regency.

\begin{abstract}
ABSTRAK
Penelitian ini bertujuan untuk menganalisis berapa besar keuntungan yang diperoleh petani dalam kegiatan usahatani bawang daun di Desa Bongkudai Utara, Kecamatan Mooat, Kabupaten Bolaang Mongondow Timur. Penelitian dilaksanakan selama 3 bulan dari bulan Oktober sampai Desember 2018. Data yang digunakan pada penelitian ini adalah data primer dan data sekunder. Pengumpulan data primer adalah melalui wawancara langsung pada 60 responden menggunakan metode stratified random sampling. Wawancara dilakukan berdasarkan kuesioner yang telah disusun sebelumnya. Data sekunder diperoleh dari Kantor Dinas Pertanian Bolaang Mongondow Timur, Kantor Desa Bongkudai Utara, Perpustakaan Fakultas Pertanian Universitas Sam Ratulangi, dan Toko Buku Lokal. Analisis dalam penelitian ini adalah analisis kualitatif dan kuantitatif yang disajikan dalam bentuk tabel kemudian dijabarkan secara deskriptif. Hasil penelitian menunjukkan bahwa jumlah keuntungan petani bawang daun per bedeng di Desa Bongkudai Utara pada strata I (lapisan bawah) sebesar Rp.426.664, sedangkan untuk strata II (Lapisan menengah) sebesar Rp.439.185 dan untuk strata III (Lapisan atas) sebesar Rp.1.227.853. Keuntungan tertinggi petani bawang daun di Desa Bongkudai Utara ada pada strata III mencapai Rp1.227.853 per bedeng. *Irreprm*
\end{abstract}

Kata kunci: penerimaan, biaya, keuntungan, Desa Bongkudai Utara, Kabupaten Bolaang Mongondow Timur.

Agrisosioekonomi:

Jurnal Transdisiplin Pertanian (Budidaya Tanaman, Perkebunan, Kehutanan, Peternakan, Perikanan), Sosial dan Ekonomi 


\section{PENDAHULUAN}

\section{Latar Belakang}

Sektor pertanian merupakan sektor yang dominan dalam kegiatan ekonomi di Indonesia, hal ini di dasarkan pada kontribusinya dalam pembentukan Produk Domestik Bruto (PDB), penciptaan kesempatan kerja, peningkatan pendapatan masyarakat, dan perolehan devisa. (Asmara dkk, 2014). Indonesia merupakan Negara pertanian yang sebagian besar pendapatan daerah berasal dari sector pertanian, artinya sektor pertanian merupakan sektor yang memegang peranan penting dalam perekonomian nasional dari seluruh sektor yang ada.

Sektor pertanian terdiri dari lima subsektor yaitu, subsektor perkebunan, subsektor peternakan, subsektor kehutanan, subsektor perikanan, dan subsektor tanaman pangan dan hortikultura. Pembangunan sektor pertanian perlu mendapat perhatian yang lebih baik agar dapat meningkatkan kemampuan untuk menghasilkan jumlah produksi yang lebih dari hasil pada umumnya (surplus) . Hal ini dapat terjadi apabila produktivitas diperbesar sehingga menghasilkan keuntungan petani yang lebih tinggi. Peningkatan taraf hidup petani diperoleh dengan cara meningkatkan keuntungannya. Untuk memperoleh keuntungan yang tinggi petani melakukan kegiatan usahatani dengan memanfaatkan lahan yang dimiliki untuk mengembangkan berbagai komoditi pertanian yang dapat menghasilkan pendapatan serta keuntungan bagi para petani. Salah satu sub sector yang sangat mempengaruhi peningkatan pendapatan adalah subsector tanaman pangan dan hortikultura.

Subsektor tanaman pangan dan hortikultura adalah bahan-bahan makanan

yang diperlukan untuk memenuhi kebutuhan sehari-hari juga sebagai salah satu subsektor yang merupakan bagian keberhasilan dalam meningkatkan produktivitas dan kualitas hasil pertanian demi kesejakteraan seluruh rakyat Indonesia. Untuk dapat menghasilkan pendapatan petani yang lebih tinggi tanaman hortikultura memiliki potensi ekonomi yang besar karena proses produksinya yang singkat dan harganya yang tinggi. Tanaman hortikultura mencakup jumlah spesies sangat banyak dan beragam yang terdiri dari tanaman buang-buahan (Frutikultur), tanaman obatobatan (Biofarmaka), tanaman bunga (Florikultura), dan tanaman tanaman sayuran (Olerikultura).

Tanaman sayuran merupakan salah satu produk pertanian yang penting bagi ketahanan pangan nasional. Tanaman sayuran selain dapat diusahakan dalam skala yang besar dapat juga diusahakan dalam skala yang kecil seperti di pekarangan. Beberapa tanaman sayuran dapat ditanam beberapa kali dalam setahun. Salah satu komoditas pertanian tanaman sayuran yang cukup menguntungkan adalah bawang daun. Bawang daun merupakan salah satu jenis sayuran yang memiliki nilai ekonomis yang tinggi digunakan sebagai bumbu masakan dan juga dapat dimanfaatkan dalam pengobatan (terapi) bermacam-macam penyakit, oleh karena itu setiap orang menggemarinya dan hampir setiap masakan memerlukannya. Jadi tidak mengherankan apabila bawang daun memegang peranan penting dalam perdagangan seiring dengan permintaan konsumen dalam pemenuhan kebutuhan sehari-hari yang merupakan sumber pendapatan bagi petani dan perekonomian negara. Sumbangan dari usahatani bawang daun cukup besar terhadap tingkat pendapatan petani, perluasan kesempatan kerja, pengembangan agribisnis dan peningkatan ekspor.

Kabupaten Bolaang Mongondow Timur adalah Kabupaten di Sulawesi Utara yang pada awalnya terdiri dari 5 (lima) kecamatan dan pada akhir tahun 2017 sudah menjadi 7 (tujuh) kecamatan salah satunya adalah Kecamatan Mooat yang mempunyai lahan pertanian yang luas dan sangat berpotensi dalam pekembangan produksi pertanian dibandingkan dengan kecamatan lainnya. Sebagian besar penduduk bermata pencaharian sebagai petani. Kecamatan Mooat dengan jumlah 10 desa termasuk desa Bongkudai Utara, memiliki potensi penghasil bawang daun dengan status lahan milik sendiri yang terdiri dari bermacam-macam besaran luas lahan yang dimiliki petani dengan jumlah komoditi yang ditanam juga berbeda-beda, dan hasil yang diproduksi dijual dengan tujuan untuk meningkatkan pendapatan keluaraga. Berdasarkan penelitian, penanaman bawang daun bukan berdasakan pada berapa luas lahan tetapi pada jumlah produksi dengan jarak tanam yang telah ditentukan pada umumnya yang dikategorikan dalam luas lahan seperempat, setengah, dan satu hektar. Hal ini disebabkan karena luas lahan yang dimiliki petani ditanami bermacam-macam tanaman hortikultura. Luas lahan yang digunakan untuk penanaman bawang daun terbagi atas 0,17 ha dan 0,19 ha yang dikategorikan dalam seperempat hektar, 0,35 dan 0,36 termasuk dalam kategori setengah hektar, kemudian 1,07 dan 1,37 termasuk dalam kategori satu hektar. Besarnya penerimaan dan keuntungan diperoleh dari banyaknya jumlah produksi(bedeng) dan disesuaikan dengan luas lahan yang akan dipakai. Kegiatan usahatani bawang daun dapat memberikan keuntungan diperoleh antara lain sumber daya di daerah ini cukup besar jumlahnya, juga bawang daun menjadi bahan pokok bagi petani 
sehingga usaha budidaya bawang daun memberikan kontribusi yang sangat besar terhadap pendapatan masyarakat pada desa ini. Besar kecilnya pendapatan dipengaruhi oleh penerimaan dan biaya produksi.

Kontribusi usahatani bawang daun di Kabupaten Bolaang Mongondow pada tahun 2014 mencapai 12.168,00 ton, tahun 2015 produksi bawang daun menurun menjadi 7.122,00 ton, dan tahun 2016 naik mencapai $14.167,00$ ton dan terus meningkat sampai pada tahun 2017 produksi bawang daun mencapai 19.662,50. Kontribusi bawang daun dapat dilihat pada Tabel 1 sebagai berikut:

\begin{tabular}{llrrrr}
\multicolumn{6}{l}{ Tabel 1. Kontribusi Bawang Daun Per Tahun } \\
\hline \multicolumn{1}{l}{ No Komoditi } & $\begin{array}{r}\text { Tahun 2014 } \\
\text { (Ton) }\end{array}$ & $\begin{array}{c}\text { Tahun 2015 } \\
\text { (Ton) }\end{array}$ & \multicolumn{1}{c}{ Tahun 2016 } \\
(Ton) & \multicolumn{1}{c}{$\begin{array}{c}\text { Tahun } 2017 \\
\text { (Ton) }\end{array}$} \\
\hline 1 & Kentang & $12.146,00$ & $13.066,98$ & $14.100,00$ & $19.587,82$ \\
2 & Kubis & $3.267,00$ & $2.587,88$ & $7.160,00$ & $6.289,96$ \\
3 & Bawang Daun & $12.168,00$ & $7.122,00$ & $14.167,00$ & $19.662,00$ \\
4 & Bawang Merah & 22,40 & 30,55 & $1.141,00$ & 766,30 \\
5 & Wortel & 980,10 & 877,43 & $7.104,86$ & $9.469,46$ \\
6 & Tomat & 935,00 & $1.087,99$ & $6.105,71$ & $9.746,71$ \\
7 & Cabe Kriting & $1.260,00$ & $1.899,00$ & 669,64 & $1.055,10$ \\
8 & Cabe Rawit & 549,00 & 576,23 & 909,08 & 542,68 \\
\hline
\end{tabular}

Tabel 1 menunjukkan bahwa peningkatan produktivitas usahatani bawang daun di Kabupaten Bolaang Mongondow Timur. Meningkatnya luas areal pengembangan budidaya bawang daun antara lain karena prospek pemasaran produksi komoditas ini makin baik. Pemasaran produksi bawang daun tidak hanya di pasarkan di daerah ini tetapi juga telah dipasarkan di luar daerah karena permintaan konsumen yang semakin meningkat. Peningkatan produksi usahatani dapat merupakan indikator keberhasilan dari usahatani yang bersangkutan, tingginya produksi suatu komoditas yang diperoleh per satuan luas tanam tidak menjamin tingginya keuntungan petani bawang daun di desa Bongkudai Utara, hal ini dipengaruhi oleh peranan masing-masing petani yang mengelola usahatani berbeda mulai dari penggunaan bibit, pemberian pupuk, pemeliharaan, teknologi yang digunakan, struktur tanah, iklim, jarak tanam,kendalakendala hama dan penyakit, serta panen sampai pada pasca panen, karena itu perlu pengelolaan yang tepat dengan menggunakan faktor produksi secara efisien agar memperoleh hasil produksi yang merata dan maksimal. Walaupun demikian, petani bawang daun di desa Bongkudai utara tetap optimis dan antusias untuk tetap berusaha meningkatkan hasil produksinya.

Bawang daun adalah salah satu sumber mata pencaharian pokok dan menjadi sumber pendapatan sebagian besar masyarakat dan petani didesa ini di samping kegiatan lainnya. Pendapatan dan keuntungan dihitung dari besarnya penerimaan dikurangi dengan seluruh biaya-biaya yang digunakan dalam pengolahan bawang daun mulai dari alat dan bahan-bahan seperti cangkul, bibit, pupuk, transportasi, tenaga kerja dan biaya lainnya yang dapat mempengaruhi besarnya keuntungan yang diperoleh petani. Namun petani di Desa Bongkudai Utara selama ini belum pernah melakukan analisis tentang berapa besar keutungan usahatani bawang daun yang diterima oleh petani. Walaupun bagi petani setempat tetap dilakukan karena usahatani ini merupakan mata pencaharian masyarakat. Oleh karena itu aspek efisiensi harus mendapat perhatian yang serius, sehingga biayabiaya yang dikeluarkan selama proses produksi dapat tertutupi dengan pendapatan dan keuntungan yang diperoleh setelah panen. Hal tersebutlah yang mendorong penulis untuk melakukan penelitian sehingga dapat mengetahui lebih lanjut keuntungan pengololahan bawang daun di Desa Bongkudai Utara kecamatan Bolaang Mongondow Timur.

\section{Pengertian Usahatani}

Usahatani adalah ilmu yang mempelajari bagaimana seorang mengusahakan dan mengkoordinir faktor-faktor produksi berupa lahan dan alam sekitarnya sebagai modal sehingga memberikan manfaat sebaik-baiknya. Sebagai ilmu pengetahuan, usahatani merupakan ilmu yang mempelajari cara-cara petani menentukan, mengorganisasikan, mengkoordinasikan penggunaan faktor-faktor produksi seefektif dan seefisien mungkin sehingga usaha tersebut memberikan pendapatan semaksimal mungkin.

Menurut Suratiyah (2009) ada beberapa definisi usahatani dari para ahli:

a. Menurut Daniel

Ilmu usahatani merupakan ilmu yang mempelajari cara-cara petani mengkombinasikan, mengoprasikan berbagai factor produksi seperti lahan, tenaga, modal sebagai dasar bagaimana petani memilih jenis dan besarnya cabang usahatani berupa tanaman atau ternak sehingga memberikan hasil yang kontinyu.

\section{b. Menurut Efferson}

Ilmu usahatani merupakan ilmu yang mempelajari cara-cara mengorganisasikan dan mengoperasikan unit usahatani dipandang dari sudut efisiensi dan pendapatan yang kontinyu.

\section{c. Menurut Vink (1984)}

Imu usahatani merupakan ilmu yang mempelajari norma-norma yang digunakan untuk mengatur usahatani agar memperoleh pendapatang yang setinggi-tingginya.

d. Menurut Prawirokusumo (1990)

Ilmu usahatani merupakan ilmu terapan yang membahas atau mempelajari bagaimana membuat atau menggunakan sumber daya secara efisien pada suatu usaha pertanian, peternakan, atau perikanan. Selain itu, juga dapat diartikan sebagai ilmu yang mempelajari bagaimana membuat dan melaksanakan keputusan pada usaha pertanian, peternakan, atau perikanan untuk mencapai tujuan yang telah di sepakati oleh petani/peternak tersebut. 


\section{Rumusan Masalah}

Usahatani bawang daun dikatakan menguntungkan bagi petani didesa Bongkudai Utara karena permintaan yang tinggi sehingga kegiatan usahatani tetap diusahakan oleh petani. Berdasarkan uraian diatas perumusan masalah dalam penelitian ini adalah berapa besar keuntungan yang diperoleh petani dalam memproduksi bawang daun?

\section{Tujuan Penelitian}

Tujuan penelitian ini adalah untuk menganalisis berapa besar keuntungan petani bawang daun yang ada di desa Bongkudai Utara Kecamatan Mooat.

\section{Manfaat Penelitian}

Penelitian ini diharapkan dapat bermanfaat bagi peneliti dalam menyelesaikan tugas akhir dan berguna bagi para petani di desa Bongkudai Utara untuk dapat mengetahui serta meningkatkan keuntungan usahatani bawang daun. Penelitian ini juga diharapkan dapat menjadi bahan refrensi dalam penelitian-penelitian selanjutnya.

\section{METODE PENELITIAN}

Waktu dan Lokasi Penelitian

Penelitian ini dilaksanakan dari bulan Oktober sampai bulan November 2018. Lokasi penelitian dilaksanakan di Desa Bongkudai Utara Kecamatan Mooat Kabupaten Bolaang Mongondow Timur.

\section{Metode Pengumpulan Data}

Data yang dibutuhkan dalam penelitian ini adalah data primer dan sekunder. Data primer adalah data yang diperoleh langsung dari petani dengan mengetahui luas lahan dan berapa jumlah bedeng serta penggunaan sarana produksi dengan cara wawancara menggunakan kuesioner. Sedangkan data sekunder adalah data yang sudah tersedia baik dokumen desa, kantor kecamatan maupun sumber lain yang terkait guna kepentingan penelitian.

\section{Metode Pengambilan Sampel}

Populasi dalam penelitian ini adalah petani bawang daun di Desa Bongkudai Utara Kecamatan Mooat yang berjumlah 160 petani. Jumlah sampel yang diambil sebanyak 60 petani dengan luas lahan milik sendiri menggunakan metode Proportional Stratified Random Sampling, yaitu teknik pengambilan sampel pada populasi heterogen dan berstrata dengan mengambil sampel dari tiap-tiap sub populasi yang jumlahnya disesuaikan dengan jumlah anggota dari masing-masing sub populasi secara acak. Dan untuk mengetahui besarnya luas lahan yang digunakan menggunakan pendekatan jarak tanam. Besaran luas lahan dapat dilihat pada Tabel 2.

\begin{tabular}{llll}
\multicolumn{5}{l}{ Tabel } & Tingkatan, Populasi, sampel \\
\hline Strata & Luas Lahan (Hektar) & Populasi & Sampel \\
\hline I & $<0,25$ & 68 & 26 \\
II & $0,26-0,50$ & 60 & 22 \\
III & $>0,51$ & 32 & 12 \\
\hline & Jumlah & 160 & 60
\end{tabular}

\section{Konsep Pengukuran Variabel} ini adalah :

Variabel-variabel yang diambil dalam penelitian

1. Luas lahan yang dikelola petani dalam usahatani bawang daun (Ha),

2. Jarak tanam antar bedeng, antar baris dan lebar bedeng.

3. Satuan produksi yang dihasilkan petani bawang daun per bedeng, per baris, dan per ikat dalam setiap luas tanam.

4. Berapa lama waktu penanaman sampai pada panen.

5. Jumlah tenaga kerja yang digunakan dalam setiap tahapan.

6. Biaya Produksi adalah jumlah pengeluaran yang dikeluarkan petani dalam satu musim tanam untuk menghasilkan bawang daun, yaitu:

a. Biaya tetap (Rp) yang terdiri dari biaya penyusutan yaitu komponen biaya yang secara tidak langsung dikeluarkan petani untuk setiap produksi, pajak, pemakaian alat-alat mesin pertanian dan sewa lahan selama usahatani bawang daun dilakukan.

b. Biaya variabel (Rp), meliputi :

a. Bibit, yaitu bahan tanam yang digunakan sebagai benih bawang daun,

b. Pupuk, yaitu zat penyubur tanah yang digunakan sebagai usaha meningkatkan produktifitas hasil usahatani bawang daun

c. Pestisida, yaitu zat antihama yang digunakan dalam pemeliharaan dan perlindungan tanaman,

d. Tenaga kerja, yaitu tenaga manusia yang dibayarkan sejak tahap persiapan usahatani bawang daun hingga masa panen,

e. Transportasi, yaitu distribusi atau pengangkutan hasil panen yang sudah siap jual dari lahan tani ke rumah atau pinggir jalan.

7. Harga jual, yaitu harga yang berlaku ditingkat petani pada saat panen (Rp)

\section{Metode Analisis Data}

Analisis data yang digunakan dalam penelitian ini yaitu analisis kuantitatif, yang terdiri dari analisis deskriptif yaitu bagian dari statistika yang mempelajari alat, teknik, atau prosedur yang digunakan untuk menggambarkan atau mendeskripsikan kumpulan data atau hasil pengamatan yang telah dilakukan antara lain mengetahui aspek-aspek apa saja yang ada dalam usahatani bawang daun, selanjutnya menghitung data yang terkumpul dan disajikan dalam bentuk tabel. Untuk mengetahui keuntungan usahatani bawang daun, dapat ditentukan dengan menggunakan rumus sebagai berikut: 
a. Penerimaan, yaitu jumlah uang yang diterima petani dalam satu kali panen, yang dihitung dgn rumus:

$$
\mathbf{T R}=\mathbf{Q} \times \mathbf{P}
$$

dimana :

$\mathrm{TR}=$ Penerimaan $(\mathrm{Rp})$

$\mathrm{Q} \quad=$ jumlah produksi $(\mathrm{kg})$

$\mathrm{P} \quad=$ harga

b. Biaya, yaitu jumlah uang yang dikeluarkan dalam proses produksi, yang dihitung dengan rumus:

dimana :

$$
\mathbf{T C}=\mathbf{F C}+\mathbf{V C}
$$

$\mathrm{TC}=$ Total biaya produksi

$\mathrm{FC}=$ Biaya Tetap $(\mathrm{Rp})$

$\mathrm{VC}=$ Biaya Variabel $(\mathrm{Rp})$

c. Keuntungan, yaitu total penerimaan dikurangi dengan total biaya dengan menggunakan rumus:

Dimana :

$$
\boldsymbol{\pi}=\mathbf{T R}-\mathbf{T C}
$$

$$
\begin{aligned}
\pi & =\text { Penghasilan Bersih } \\
\mathrm{TR} & =\text { Total penerimaan } \\
\mathrm{TC} & =\text { Total biaya }
\end{aligned}
$$

\section{HASIL DAN PEMBAHASAN}

\section{Gambaran Umum Wilayah Penelitian}

\section{Keadaan Wilayah Penelitian Desa Bongkudai Utara}

Desa Bongkudai Utara terletak di Kecamatan Mooat Kabupaten Bolaang Mongondow Timur Sulawesi Utara dengan batas-batas wilayah sebagai berikut:

1. Sebelah utara berbatasan dengan Desa Bongkudai Timur, Kecamatan Mooat

2. Sebelah timur berbatasan dengan Desa Guaan, Kecamatan Mooat

3. Sebelah selatan berbatasan dengan Desa Bongkudai Baru

4. Sebelah Barat berbatasan dengan perkebunan menuju Insil

Luas wilayah keseluruhan Desa Bongkudai Utara adalah 349 Hektar, dengan Pembagian cakupan wilayah untuk lahan pemukiman 98 ha, lahan ladang 250, serta luas kuburan 1 ha. Desa Bongkudai Utara dibagi dalam 7 dusun dan setiap dusun terdiri dari 1 Rukun tetangga (RT).

\section{Keadaan Penduduk}

Penduduk merupakan orang-orang yang berada didalam suatu wilayah geografi dan ruang

\begin{tabular}{|c|c|c|c|}
\hline No & Jenis Kelamin & Jumlah Jiwa & $\mathrm{p}(\%)$ \\
\hline 1 & Laki-Laki & 510 & 46,4 \\
\hline 2 & Perempuan & 590 & 53,6 \\
\hline & Jumlah & 1.100 & 100,0 \\
\hline
\end{tabular}
tertentu. Berdasarkan penelitian jumlah penduduk yang berdomisili di Desa Bongkudai Utara adalah sebanyak 1.100 Jiwa. Untuk mengetahui jumlah jiwa yang dibagi dalam jenis kelamin dapat dilihat pada Tabel 3.
Tabel 3 menunjukkan bahwa di Desa Bongkudai Utara, yang berjenis kelamin laki-laki sebanyak 510 jiwa atau (46,4\%), sedangkan jumlah penduduk berjenis kelamin perempuan sebanyak 590 atau $(53,6 \%)$ dari total keseluruhan jumlah penduduk.

\section{Karakteristik Responden}

Karakteristik responden yang mengusahakan produksi bawang daun di tempat penelitian yang dimaksud adalah kelompok usia dan tingkat pendidikan para produsen bawang daun. Kelompok usia dan tingkat pendidikan dapat diuraikan sebagai berikut:

\section{Umur Responden}

Umur seseorang akan sangat berpengaruh dalam melakukan kegiatan usahatani untuk mendapatkan keuntungan, jika usia masih termasuk

\begin{tabular}{|c|c|c|c|c|c|c|}
\hline \multirow[t]{2}{*}{ Strata } & \multirow[t]{2}{*}{ Luas Lahan (Ha) } & \multicolumn{4}{|c|}{ Umur(tahun) } & \multirow{2}{*}{$\begin{array}{c}\text { Jumlah } \\
\text { Responden }\end{array}$} \\
\hline & & $20-30$ & $31-40$ & $41-50$ & $>50$ & \\
\hline I & $<0,25$ & 4 & 12 & 7 & 3 & 26 \\
\hline II & $0,26-0,50$ & 0 & 6 & 12 & 4 & 22 \\
\hline \multirow[t]{2}{*}{ III } & $>0,51$ & 0 & 6 & 6 & 0 & 12 \\
\hline & Jumlah & 4 & 24 & 25 & 7 & 60 \\
\hline
\end{tabular}
dalam kategori usia produktif maka petani dapat melakukan kegiatan usahatani lebih banyak. Hasil penelitian menunjukkan bahwa yang termasuk kategori usia produktif dapat dilihat pada Tabel 4 yang diklasifikasikan per luas lahan.

Tabel 4 menunjukkan bahwa pada strata I sebaran umur yang paling banyak berada di umur 31-40 tahun sebanyak 12 responden, pada strata II sebaran umur yang paling banyak berada pada umur 41-50 tahun sebanyak 12 responden, dan pada strata III sebaran umur 31-40 tahun dan 41-50 tahun masing masing sebanyak 6 responden.

\section{Tingkat Pendidikan Responden}

Pendidikan merupakan kebutuhan pokok bagi setiap masyarakat. Pendidikan seseorang dapat mempengaruhi pola pikir, sikap dan tindakan dalam memiliki potensi sumber daya bidang pertanian. Berdasarkan hasil penelitian mayoritas responden yang diteliti memiliki tingkat pendidikan yang relative rendah. Tingkat pendidikan reponden dapat dilihat pada Tabel 5 . 
Tabel 5. Tingkat Pendidikan Responden

\begin{tabular}{|c|c|c|c|c|c|c|c|}
\hline \multirow[t]{2}{*}{ Strata } & \multirow{2}{*}{$\begin{array}{l}\text { Luas Lahan } \\
\text { (Ha) }\end{array}$} & \multicolumn{5}{|c|}{ Tingkat Pendidikan } & \multirow{2}{*}{$\begin{array}{c}\text { Jumlah } \\
\text { Responden }\end{array}$} \\
\hline & & SD & SMP & SMA & SMK & $\begin{array}{l}\text { Perguruan Tinggi } \\
\end{array}$ & \\
\hline I & $<0,25$ & 6 & 14 & 2 & 2 & 2 & 26 \\
\hline II & $0,26-0,50$ & 3 & 10 & 4 & 4 & 1 & 22 \\
\hline III & $>0,51$ & 0 & 8 & 3 & 0 & 1 & 12 \\
\hline & Jumlah & 9 & 32 & 9 & 6 & 4 & 60 \\
\hline
\end{tabular}

Sumber: Data Primer, Tahun 2018 (diolah)

Tabel 5 menunjukkan bahwa untuk strata I dengan luas lahan $<0,25$ ha bahwa sebaran tingkat pendidikan responden paling banyak yaitu berpendidikan SMP sebanyak 14 responden, dan untuk strata II dengan luas lahan $0,26-0,50$ ha tingkat pendidikan paling banyak adalah SMP sebanyak 10 responden, dan strata III dengan lahan > 0,51 ha tingkat pendidikan yang paling banyak adalah pendidikan SMP sebanyak 8 responden. Dengan demikian bahwa tingkat pendidikan petani bawang daun di Desa Bongkudai Utara Kecamatan Mooat berdasarkan penelitian kebanyakan rendah namun walaupun rendah, pengalaman mereka cukup memadai sehingga diharapkan produktivitas dan pendapatan semakin meningkat.

\section{Luas Lahan}

Luas lahan yang dimaksud dalam penelitian ini adalah luas lahan yang ditanami bawang daun yang sangat mempengaruhi besar kecilnya keuntungan. Luas lahan yang ditanami bawang daun berbentuk bedeng dengan ukuran lebar bedeng 0,7 meter dan panjang bedeng 50 dan 100 meter, jarak antar bedeng 0,5 meter, dan jarak antar baris 0,3 meter.

Semua lahan pertanian yang dimiliki responden di Desa Bongkudai Utara adalah miliknya sendiri. Luas lahan berpengaruh terhadap produktivitas usahatani dimana usahatani dengan luas yang lebih besar akan memiliki hasil produksi yang lebih tinggi dibandingkan dengan usahatani yang luas lahannya lebih kecil. Berdasarkan penelitian luas lahan petani bawang daun bervariasi, dapat dilihat pada Tabel 6 .

Tabel 6. Luas Lahan, dan Jumlah Responden

\begin{tabular}{|c|c|c|c|}
\hline Strata & Kategori Luas Lahan (Ha) & Luas Lahan (Ha) & Responden (orang) \\
\hline \multirow[t]{2}{*}{ I } & $<0,25$ & 0,17 & 14 \\
\hline & & 0,19 & 12 \\
\hline \multirow[t]{2}{*}{ II } & $0,26-0,50$ & 0,35 & 9 \\
\hline & & 0,36 & 13 \\
\hline \multirow[t]{3}{*}{ III } & $>0,51$ & 1,37 & 5 \\
\hline & & 1,07 & 7 \\
\hline & Jumlah & & 60 \\
\hline
\end{tabular}

Sumber: Data Primer, Tahun 2018 (diolah)

Tabel 6 menunjukkan bahwa, Strata I untuk luas lahan bawang daun kategori $<0,25$ hektar terbagi atas dua yaitu 0,17 ha sebanyak 14 responden dan 0,19 ha sebanyak 12 responden, sedangkan strata II kategori luas lahan 0,26-0,50 hektar terbagi atas 0,35 ha sebanyak 9 responden dan 0,36 sebanyak 13 responden, dan strata III kategori luas lahan > 0,51 ha terbagi atas 1,37 ha sebanyak 5 renponden dan 1,07 sebanyak 7 responden.

\section{Hasil Produksi}

Produksi adalah semua hasil bawang daun dalam bentuk ikat yang diusahakan oleh petani untuk dijual sesuai harga yang telah dipasarkan yang dapat menambah keuntungan bagi petani. Hasil produksi reponden dapat dilihat pada Tabel 7.

\begin{tabular}{|c|c|c|c|c|c|c|}
\hline \multirow[t]{2}{*}{ Strata } & \multirow{2}{*}{$\begin{array}{l}\text { LuasLahan } \\
\text { (Ha) }\end{array}$} & \multirow{2}{*}{$\begin{array}{c}\text { Kategori Luas } \\
\text { Lahan (Ha) }\end{array}$} & \multicolumn{2}{|c|}{ Produksi } & \multirow{2}{*}{$\begin{array}{c}\begin{array}{c}\text { Jumlah } \\
\text { Produksi } \\
\text { (Satuan) }\end{array} \\
\text { Ikat } \\
\end{array}$} & \multirow{2}{*}{$\begin{array}{c}\text { Respnden } \\
\text { (Orang) }\end{array}$} \\
\hline & & & Bedeng & Baris & & \\
\hline \multirow[t]{2}{*}{ I } & 0,17 & $<0,25$ & 30 & 165 & 4.950 & 14 \\
\hline & 0,19 & & 35 & 160 & 5.600 & 12 \\
\hline \multirow[t]{2}{*}{ II } & 0,35 & $0,26-0,50$ & 60 & 165 & 9.900 & 13 \\
\hline & 0,36 & & 65 & 160 & 10.400 & 9 \\
\hline \multirow[t]{3}{*}{ III } & 1,37 & $>0,51$ & 110 & 350 & 38.500 & 5 \\
\hline & 1,07 & & 120 & 300 & 36.000 & 7 \\
\hline & Jumlah & & & & & 60 \\
\hline
\end{tabular}

Tabel 7 menunjukkan bahwa hasil produksi lebih tinggi terdapat pada strata III luas lahan 1,37 denga jumlah bedeng 110 dapat menghasilkan 38.500 ikat, dan luas lahan 1,07 dengan jumlah bedeng 120 menghasilkan 36.000 ikat. Sedangkan hasil produksi yang rendah ada pada strata 1 dengan jumlah bedeng 30 dapat menhasilkan 4.950 ikat dan 35 bedeng menghasilkan 5.600 ikat. Dalam setiap bedeng terdapat 165 dan 160 baris dan setiap baris menghasilkan 1 ikatan sehingga hasil produksi bawang daun dihitung dari banyaknya jumlah bedeng dikali dengan jumlah baris.

\section{Penggunaan Sarana Produksi}

Sarana Produksi merupakan bahan yang sangat menentukan di dalam budidaya tanaman, yaitu suatu sarana yang ada hubungannya dengan pertumbuhan tanaman di lapangan seperti benih/bibit, pupuk, pestisida pengendali hama dan penyakit pada tanaman dan alat-alat pertanian. a. Bibit

Jumlah bibit sangat mempengaruhi hasil produksi bawang daun, ketika jumlah bibit banyak dan didukung oleh luas lahan maka akan mempengaruhi jumlah produksi bawang daun. Bibit yang diperlukan jumlahnya berbeda-beda disetiap luas lahan. Bibit yang dimaksud yaitu bibit anakan atau tunas. Penggunaan bibit dapat dilihat pada Tabel 8.

Tabel 8. Penggunaan Bibit Berdasarkan Luas Lahan

\begin{tabular}{cccc}
\hline Strata & $\begin{array}{c}\text { Kategori Luas } \\
\text { Lahan (Ha) }\end{array}$ & $\begin{array}{c}\text { Luas Lahan } \\
\text { (Ha) }\end{array}$ & $\begin{array}{c}\text { Jumlah Bibit } \\
\text { (Bedeng) }\end{array}$ \\
\hline I & $<0,25$ & 0,17 & 6 \\
& & 0,19 & 7 \\
II & $0,26-0,50$ & 0,35 & 12 \\
& & 0,36 & 13 \\
III & $>51$ & 1,37 & 22 \\
& & 1,07 & 24 \\
\hline
\end{tabular}

Sumber: Data Primer, Tahun 2018 (diolah) 
Tabel 8 menunjukkan bahwa penggunaan bibit lebih banyak yaitu pada strata III sebnyak 22 dan 24 bedeng bibit, sedangkan yang paling sedikit penggunaan bibitnya ada pada strata I sebanyak 6 dan 7 bedeng bibit, kemudian strata II sebanyak 12 dan 13 bedeng bibit.

b. Pupuk

Pemupukan dilakukan oleh petani untuk meningkatkan kualitas bawang daun sehingga memperoleh hasil lewat penambahan zat makanan bagi tanaman yang dibudidayakan untuk memenuhi kebutuhan unsur hara. Dalam pemupukan terdapat 4 jenis pupuk yang digunakan oleh petani yaitu pupuk kandang, pupuk SP, pupuk Urea, dan pupuk ponska. Pengunaan jenis pupuk disesuaikan dengan jumlah bedeng, kondisi tanah dan pengalaman bertani. Penggunaan pupuk dapat dilihat pada Tabel 9.

\begin{tabular}{ccccccc}
\multicolumn{2}{c}{ Tabel 9. Penggunaan Pupuk Berdasarkan Jumlah Produksi } \\
\hline Strata & $\begin{array}{c}\text { Luas Lahan } \\
\text { (Ha) }\end{array}$ & $\begin{array}{c}\text { Pupuk Kandang } \\
\text { (Karun) }\end{array}$ & $\begin{array}{c}\text { Sp } \\
\text { (Karung) }\end{array}$ & $\begin{array}{c}\text { Ponska } \\
\text { (Karung) }\end{array}$ & $\begin{array}{c}\text { Urea } \\
\text { (Karung) }\end{array}$ \\
\hline I & $<0,25$ & 0,17 & 30 & 2 & 2 & 1 \\
& & 0,19 & 35 & 2 & 2 & 1 \\
II & $0,26-0,50$ & 0,35 & 60 & 4 & 4 & 3 \\
& & 0,36 & 65 & 4 & 4 & 3 \\
III & $>51$ & 1,37 & 110 & 15 & 15 & 5 \\
& & 1,07 & 120 & 15 & 15 & 5 \\
\hline
\end{tabular}

Tabel 9 menunjukkan bahwa petani Strata III lebih banyak pupuk yang digunakan karena luas lahan dan jumlah bedeng yang ditanam lebih banyak dibandingkan dengan petani pada strata I dan Strata II.

c. Pestisida

Penyakit pada tanaman dapat menyebabkan kerusakan dan mengakibatkan penurunan produktivitas usahatani. Penyakit pada tanaman ini berupa virus dan bakteri. Sebagian besar petani menggunakan cara kimiawi untuk penanganan masalah tersebut yaitu dengan memberikan pestisida kimiawi untuk memberikan efek yang lebih cepat. Penggunaan pestisida pada bawang daun dapat dilihat pada Tabel 10.

Tabel 10. Penggunaan Pestisida
\begin{tabular}{ccccccc} 
Strata $\begin{array}{c}\text { Luas Lahan } \\
\text { (Ha) }\end{array}$ & $\begin{array}{c}\text { Byfolan } \\
\text { (Botol) }\end{array}$ & $\begin{array}{c}\text { Korakron } \\
\text { (Botol) }\end{array}$ & $\begin{array}{c}\text { Korona } \\
\text { (Botol) }\end{array}$ & $\begin{array}{c}\text { Sidametrin } \\
\text { (Botol) }\end{array}$ & $\begin{array}{c}\text { Sples-sples } \\
\text { (Botol) }\end{array}$ \\
\hline I & $<0,25$ & 2 & 1 & 1 & 1 & 1 \\
II & $0,26-0,50$ & 3 & 2 & 2 & 2 & 2 \\
III & $>0,51$ & 5 & 3 & 3 & 3 & 3 \\
\hline
\end{tabular}
Sumber: Data Primer, Tahun 2018 (diolah)

Tabel 10 menunjukkan bahwa penggunaan pestisida terbanyak adalah pada strata III, dikarenakan jumlah produksi bedeng lebih banyak dibandingkan dengan strata I dan II. Pestisida diberikan 1 kali dalam seminggu, sehingga dalam masa tanam selama 3 bulan penggunaan pestisida mencapai 12 kali.

\section{d. Tenaga Kerja}

Tenaga kerja manusia sangat dibutuhkan dalam proses produksi bawang daun, proses produksi bawang daun dilakukan bertahap yaitu persiapan lahan, penanaman, pemeliharaan, pemupukan, dan penyemprotan setiap tahap penggunaan tenaga kerja masing-masing jumlahnya berbeda-beda. Penggunaan tenaga kerja dapat dilihat pada Tabel 11.

\begin{tabular}{ccccccc}
\multicolumn{6}{c}{ Tabel 11. Jumlah Tenaga Kerja Dalam Usahatani Berdasarkan Produksi } \\
\hline $\begin{array}{ccccc}\text { Strata Luas Lahan } \\
\text { (Ha) }\end{array}$ & $\begin{array}{c}\text { Persiapan } \\
\text { Lahan }\end{array}$ & Penanaman & Pemeliharaan Kerja & Pemupukan & Penyemprotan \\
\hline I & $<0,25$ & 8 & 8 & 4 & 2 & 2 \\
& & 9 & 9 & 6 & 2 & 2 \\
II & $0,26-0,50$ & 15 & 15 & 10 & 4 & 4 \\
& & 16 & 16 & 10 & 4 & 4 \\
III & $>51$ & 28 & 28 & 20 & 7 & 7 \\
& & 30 & 30 & 20 & 8 & 8 \\
\hline
\end{tabular}

Sumber: Data Primer, Tahun 2018 (diolah)

Tabel 11 menunjukkan bahwa penggunaan tenaga kerja terbanyak pada strata III dengan jumlah bedeng 110 bedeng peggunaan tenaga kerja dalam persiapan lahan dan penanaman masing-masing 28 tenaga kerja, pemeliharaan 20 tenaga kerja, pemupukan dan penyemprotan masing-masing 7 tenaga kerja, dan jumlah produksi 120 bedeng persiapan lahan dan penanaman masing-masing 30 tenaga kerja, pemeliharaan 20 tenaga kerja, pemupukan dan penyemprotan masing-masing 8 tenaga kerja. Setiap tenaga kerja dalam persiapan lahan dan penanaman dapat menyelesaikan 4 bedeng.

\section{Biaya Produksi Usahatani Bawang Daun}

Biaya Produksi adalah semua biaya yang dikeluarkan petani untuk memproduksi bawang daun selama satu kali proses produksi atau masa tanam yang dibagi dalam biaya tetap dan biaya variabel.

1. Biaya Tetap

Biaya tetap yang dimaksud adalah seluruh biaya alat dan penyusutan serta sewa lahan dan pajak yang dikeluarkan selama satu kali proses usahatani bawang daun. Biaya-biaya tetap dapat dijelaskan sebagai berikut.

\section{a. Biaya Alat dan Penyusutan}

Biaya penyusutan yang secara tidak langsung dikeluarkan petani untk setiap kali proses produksi dalam hal ini adalah alat-alat pertanian dan mesinmesin pertanian selama dilakukan usahatani bawang daun. Biaya penyusutan dihitung dengan formulasi nilai beli dikurangi dengan harga jual, kemudian dibagi dengan umur ekonomis kemudian dibagi dengan 15, karena pemakaian alat 5 tahun dan dalam satu tahun tiga kali produksi . Harga jual didapat dari perhitungan 5\% dari harga beli. Alat-alat yang digunakan dalam produksi bawang daun adalah sekop, parang, dan tengki. Jenis-jenis alat yang digunakan dapat dilihat pada Tabel 12. 
Tabel 12. Biaya alat dan Penyusutan

\begin{tabular}{|c|c|c|c|}
\hline No & Nama & Jumlah (Rp) & Penyusutan (Rp) \\
\hline 1 & Sekop & 120.000 & 1520 \\
\hline 2 & Parang & 65.000 & 823 \\
\hline \multirow[t]{2}{*}{3} & Tengki & 525.000 & 6650 \\
\hline & Jumlah & 710.000 & 8993 \\
\hline
\end{tabular}

Sumber: Data Primer, Tahun 2018 (diolah)

Tabel 12 menunjukkan bahwa biaya alat pertanian sekop dengan harga Rp.120.000, harga jual Rp.6000 sehingga penyusutannya berjumlah Rp.1520, sedangkan untuk harga parang berjumlah Rp.65.000, harga jual Rp.3250 sehingga penyusutan berjumlah Rp.823, dan harga tengki berjumlah Rp.525.000, harga jual Rp.26.250 sehingga biaya penyusutannya Rp.6650 dan jumlah keseluruhan untuk biaya penyusutan sebesar Rp.8993.

\section{b. Sewa Lahan}

Biaya sewa lahan juga harus diperhitungkan sekalipun lahan yang ditanami bawang daun adalah milik sendiri dari petani agar dapat menghitung seluruh keuntungan yang didapat oleh petani pengusaha bawang daun. Sewa lahan untuk 1 ha sebesar Rp.2.000.000. Biaya sewa lahan dapat dilihat pada Tabel 13.

\begin{tabular}{cccr}
\multicolumn{2}{l}{ Tabel 13. Biaya Sewa Lahan } & \\
\hline Strata & $\begin{array}{c}\text { Kategori } \\
\text { Luas Lahan (Ha) }\end{array}$ & $\begin{array}{c}\text { Luas Lahan } \\
\text { Produksi (Ha) }\end{array}$ & Sewa Lahan (Rp) \\
\hline I & $<0,25$ & 0,17 & 340.000 \\
& & 0,19 & 380.000 \\
II & $0,26-0,50$ & 0,35 & 700.000 \\
& & 0,36 & 720.000 \\
III & $>0,51$ & 1,07 & 2.140 .000 \\
& & 1,37 & 2.740 .000 \\
\hline \multicolumn{2}{l}{ Sumber: Data Primer, Tahun 2018 (diolah) } &
\end{tabular}

Tabel 13 menunjukkan bahwa semakin besar lahan yang digunakan dalam mengusahakan bawang daun maka semakin besar biaya sewa lahan yang dikeluarkan. Cara menghitung biaya sewa lahan yaitu Rp.2.000.000(Biaya sewa $1 \mathrm{Ha}$ ) dibagi dengan 100 kemudian dikali dengan besarnya luas lahan yang digunakan.

c. Pajak

Pajak adalah pungutan uang wajib yang dibayar oleh petani sesuai dengan luas lahan yang digunakan untuk menanam bawang daun, dan setiap luas lahan biaya pajak berbeda-beda. Biaya pajak dapat dilihat pada Tabel 14.

\begin{tabular}{|c|c|c|}
\hline Strata & Luas Lahan (Ha) & Pajak (Rp) \\
\hline I & $<0,25$ & 5.000 \\
\hline II & $0,26-0,50$ & 10.000 \\
\hline III & $>0,51$ & 20.000 \\
\hline
\end{tabular}

Tabel 14 menunjukkan bahwa strata I luas lahan $<0,25$ ha biaya pajak sebesar Rp.5000, sedangkan untuk strata II luas lahan $0,26-0,50$ ha biaya pajak sebesar Rp.10.000, dan untuk strata III luas lahan > 0,51 ha sebesar Rp.20.000. Besar kecilnya jumlah pajak tergantung pada luas lahan yang digunakan.

\section{Biaya Variabel}

Biaya variabel adalah biaya yang dikeluarkan petani dalam kegiatan produksi uusahatani bawang daun. Berdasarkan penelitian yang termasuk dalam biaya variabel adalah bibit,pupuk,pestisida, tenaga kerja, transportasi, dan pajak.

a. Bibit

Bibit merupakan bahan pokok tanam yang dibutuhkan dalam proses produksi bawang daun, semakin besar jumlah luas lahan untuk penanaman bawang daun maka semakin banyak jumlah bibit yang di perlukan. Jumlah bibit yang digunakan sesuai kebutuhan per jumlah bedeng. Penggunaan bibit dapat dilihat pada Tabel 15 .

Tabel 15. Penggunaan Bibit

\begin{tabular}{ccccr}
\hline Strata & $\begin{array}{c}\text { Luas Lahan } \\
\text { (Ha) }\end{array}$ & $\begin{array}{c}\text { JumlahProduksi } \\
\text { (Ikat) }\end{array}$ & $\begin{array}{c}\text { Jumlah Bibit } \\
\text { (Bedeng) }\end{array}$ & Total Biaya (Rp) \\
\hline I & $<0,25$ & 30 & 6 & 6.000 .000 \\
& & 35 & 7 & 7.000 .000 \\
II & $0,26-0,50$ & 60 & 12 & 12.000 .000 \\
& & 65 & 13 & 13.000 .000 \\
III & $>0,51$ & 110 & 22 & 22.000 .000 \\
& \multicolumn{5}{l}{ Sumber: Data Primer, Tahun 2018 (diolah) } \\
\multicolumn{7}{l}{}
\end{tabular}

Tabel 15 menunjukkan bahwa biaya bibit terbanyak pada strata III sebesar Rp.22.000.000 dan Rp.24.000.000, sedangkan strata II sebesar Rp.12.000.000 dan Rp.13.000.000, dan strata I sebesar Rp.6.000.000 dan Rp.7.000.000. Biaya bibit untuk 1 bedeng sebesar Rp. 1.000.000. Sehingga cara menghitung biaya bibit adalah harga bibit dikali dengan jumlah penggunaan bibit sama dengan besarnya biaya bibit yang dikeluarkan.

b. Pupuk

Pupuk adalah termasuk dalam kebutuhan yang penting dalam proses produksi bawang daun karena pupuk dapat menjadikan tanaman untuk mengsilkan produksi yang berkualitas. Semakin bnyak jumlah bedeng maka semakin banyak juga pupuk yang akan digunakan. Penggunaan biaya pupuk dapat dilihat pada Tabel 16.

\begin{tabular}{|c|c|c|c|c|c|c|c|}
\hline \multirow{3}{*}{$\begin{array}{c}\text { Srata } \\
\text { I }\end{array}$} & \multicolumn{2}{|c|}{$\begin{array}{l}\text { Luas Lahan } \\
\text { (Ha) }\end{array}$} & \multirow{3}{*}{$\begin{array}{c}\begin{array}{c}\text { Pupuk } \\
\text { Kandang } \\
\text { (Rp) }\end{array} \\
600.000 \\
700.000\end{array}$} & \multirow{2}{*}{$\begin{array}{c}\begin{array}{c}\text { Sp } \\
(\mathbf{R p})\end{array} \\
230.000\end{array}$} & \multirow{2}{*}{$\begin{array}{r}\text { Ponska (Rp) } \\
230.000\end{array}$} & \multirow{2}{*}{$\begin{array}{c}\text { Urea (Rp) } \\
105.000\end{array}$} & \multirow{3}{*}{$\begin{array}{c}\begin{array}{c}\text { Total } \\
\text { (Rp) }\end{array} \\
1.165 .000 \\
1.265 .000\end{array}$} \\
\hline & $<0,25$ & $\begin{array}{l}0,17 \\
0,19\end{array}$ & & & & & \\
\hline & & 0,19 & & 230.000 & 230.000 & 105.000 & \\
\hline \multirow[t]{2}{*}{ II } & $0,26-0,50$ & 0,35 & 1.200 .000 & 460.000 & 460.000 & 315.000 & 2.435 .000 \\
\hline & & 0,36 & 1.300 .000 & 460.000 & 460.000 & 315.000 & 2.535 .000 \\
\hline \multirow[t]{2}{*}{ III } & $>0,51$ & 1,37 & 2.200 .000 & 1.725 .000 & 1.725 .000 & 525.000 & 6.175 .000 \\
\hline & & 1,07 & 2.400 .000 & 1.725 .000 & 1.725 .000 & 525.000 & 6.375 .000 \\
\hline
\end{tabular}

Tabel 16 menunjukkan bahwa total biaya pupuk yang lebih banyak adalah pada strata III yaitu jumlah produksi 110 bedeng total biaya pupuk sebesar Rp.6.175.000 dan 120 bedeng sebesar Rp.6.375.000. Sedangkan strata I biaya pupuk sebesar Rp.1.165.000 untuk 30 bedeng, dan Rp.1.265.000 untuk 35 bedeng dan pada strata II biaya pupuk sebesar Rp.2.435.000 untuk 60 bedeng dan Rp.2.535.000 untuk 65 bedeng. Harga pupuk kandang dalam 1 bantal sebesar 
Rp.20.000, pupuk Sp Rp.115.000, pupuk ponska Rp.115.000 dan pupuk urea Rp.105.000. Cara menghitung biaya pupuk yaitu dengan mengkalikan jumlah penggunaan sarana produksi pupuk dengan harga.

\section{c. Pestisida}

Penggunaan pestisida bermaksud untuk melindungi/menghindarkan tanaman dari serangan hama dan penyakit yang dapat menyebabkan kualitas tanaman menjadi tidak baik dan berdampak pada harga dan pendapatan petani menurun. Biaya yang dikeluarkan untuk pestisida dapat dilihat pada Tabel 17.

\section{Tatel 17.Peagunan Pestisita}

\begin{tabular}{|c|c|c|c|c|c|c|c|}
\hline \multirow{2}{*}{\multicolumn{2}{|c|}{ Strats Lus Labun (Ha) }} & \multicolumn{2}{|c|}{ Briflat Sples-Sples } & \multirow{2}{*}{$\begin{array}{c}\text { Korves } \\
\text { (Rp) }\end{array}$} & \multicolumn{3}{|c|}{ Korakron Sdantetrin Total (Kp) } \\
\hline & & (Rp) & $(\mathbb{B})$ & & $(\mathbb{R p})$ & $(\mathbb{B y})$ & \\
\hline I & $<0,5 \quad 0,17 \tan 0,19$ & 56000 & 35.200 & 150000 & 130000 & 55600 & $436 ?$ \\
\hline II & $0,26.3,500,0,55$ tan 0,35 & 84.00 & T2500 & 30000 & 30000 & Q0.005 & 844003 \\
\hline III & $>05 ! \quad 137 \tan 107$ & 140.000 & 105000 & 45000 & 45000 & 135,000 & 1280050 \\
\hline
\end{tabular}

Tabel 17 menunjukkan bahwa biaya pestisida terbanyak pada strata III sebesar Rp.1.280.000 dibandingkan dengan strata I sebesar Rp.436.000 dan strata II sebesar Rp.844.000. Harga pestisida per botol adalah Korakron Rp.150.000, korona Rp.150.000, byfolan Rp 28.000, sples-sples Rp. 35.000 dan sidametrin Rp.45.000. Cara menghitung biaya pestisida adalah dengan mengalikan jumlah penggunaan sarana produksi pestisida dengan harga. d. Tenaga Kerja

Tenaga kerja yang digunakan dalam proses produksi masing-masing jumlah bedeng berbeda. Maka biaya tenaga kerja dalam setiap jumlah bedeng berbeda juga. Setiap tenaga kerja dihitung 6 jam kerja/hari dengan biaya Rp.120.000/6 jam untuk 1 tenaga kerja. Biaya tenaga kerja dalam proses usahatani dapat dilihat pada Tabel 18.

\begin{tabular}{ccccc}
\multicolumn{6}{l}{ Tabel 18. Tenaga Kerja } \\
\hline Strata & $\begin{array}{c}\text { Luas Lahan } \\
\text { (Ha) }\end{array}$ & $\begin{array}{c}\text { Produksi } \\
\text { (Bedeng) }\end{array}$ & $\begin{array}{c}\text { Jumlah Tenaga } \\
\text { Kerja (Orang) }\end{array}$ & $\begin{array}{c}\text { Total Biaya } \\
\text { (Rp) }\end{array}$ \\
\hline I & $<0,25$ & 30 & 24 & 2.880 .000 \\
& & 35 & 28 & 3.360 .000 \\
II & $0,26-0,50$ & 60 & 48 & 5.760 .000 \\
& & 65 & 50 & 6.000 .000 \\
III & $>0,51$ & 110 & 90 & 10.800 .000 \\
& & 120 & 96 & 11.520 .000 \\
\hline
\end{tabular}

Tabel 18 menunjukkan bahwa banyaknya biaya tenaga kerja adalah pada strata III sebanyak Rp.10.800.000 dan Rp.11.520.000 dikarenakan jumlah produksi bedeng lebih banyak dibandingkan dengan strata I dan strata II. Dengan demikian untuk menghitung biaya tenaga kerja adalah jumlah tenaga kerja dikali dengan biaya tenaga kerja per hari.

\section{e. Transportasi}

Transportasi adalah biaya yang dikeluarkan selama proses produksi bawang daun. Alat transportasi yang digunakan adalah motor, dalam setiap petani memiliki jumlah transportasi yang berbeda-beda, karna ada yang jarak dekat dengan lahan yang ditanami bawang daun dan ada yang jarak jauh dengan lahan kegiatan produksi bawang. Setiap petani ada yang mengeluarkan biaya transportasi sebesar Rp.36.000, Rp.27.000, dan Rp.50.000, biaya transportasi yang dimaksud adalah biaya untuk membeli minyak bensin motor untuk pergi ke kebun termasuk dengan pengangkutan pupuk. Besar kecilnya biaya transportasi tergantung pada jarak tempuh lokasi produksi bawang daun masing-masing petani dengan tempat tinggal.

\section{Penerimaan Usahatani}

Penerimaan dalam usahatani bawang daun adalah perkalian antara jumlah produksi dan harga jual yang telah ditentukan oleh besar kecilnya jumlah produksi dan harga jual yang berlaku saat itu diwilayah penelitian. Dengan demikian penerimaan petani bawang daun tergantung besarnya luas lahan, jumlah produksi dan harga pasar. Penerimaan petani dalam produksi bawang daun per luas lahan dapat dilihat pada Tabel 19.

\begin{tabular}{ccccr}
\multicolumn{5}{l}{ Tabel 19. Penerimaan Usahatani Bawang Daun } \\
\hline Strata & $\begin{array}{c}\text { Luas Lahan } \\
\text { (Ha) }\end{array}$ & $\begin{array}{c}\text { Jumlah } \\
\text { Produksi (Ikat) }\end{array}$ & Harga (Rp) & Penerimaan (Rp) \\
\hline I & $<0,25$ & 4.950 & 5000 & 24.750 .000 \\
& & 5.600 & 5000 & 28.000 .000 \\
II & $0,26-0,50$ & 9.900 & 5000 & 49.500 .000 \\
& & 10.400 & 5000 & 52.000 .000 \\
III & $>0,51$ & 38.500 & 5000 & 192.500 .000 \\
& & 36.000 & 5000 & 180.000 .000 \\
\hline \multicolumn{5}{l}{ Sumber: Data Primer, Tahun 2018 (diolah) } \\
\end{tabular}

Tabel 19 menunjukkan bahwa penerimaan usahatani terbesar adalah strata III untuk luas lahan > 0,51 Hektar dengan jumlah produksi 110 bedeng 38.500 ikat jumlah penerimaannya sebesar Rp.192.500.000, dan untuk 120 bedeng 36.000 ikat jumlah penerimaan sebesar Rp.180.000.000, sedangkan strata I untuk luas lahan $<0,25$ hektar yang dibagi atas 2 yaitu 30 bedeng dengan jumlah produksi 4950 ikat penerimaannya sebesar Rp.24.750.000 dan untuk 35 bedeng dengan jumlah produksi 5600 ikat penerimaanya sebesar Rp.28.000.000 dan penerimaan usahatani strata II untuk luas lahan 0,26-0,50 hektar dibagi menjadi 2 yaitu 60 bedeng dengan jumlah produksi 9900 ikat penerimaannya sebesar Rp.49.500.000, dan untuk 65 bedeng jumlah produksi 10400 ikat penerimaannya sebesar Rp.52.000.000, dan penerimaan bawang daun di desa Bongkudai Utara Kecamatan Mooat. Cara menghitung penerimaan adalah dengan mengkalikan jumlah produksi dengan harga Rp.5.000. 


\section{Keuntungan Usahatani}

Besarnya keuntungan yang diterima petani merupakan hasil dari jumlah keseluruhan penerimaan dikurangi dengan seluruh biaya-biaya yang terdiri dari biaya variabel dan biaya tetap. Keuntungan yang diperoleh dapat dilihat pada Tabel 20.

Tabel 20 menunjukkan bahwa keuntungan untuk strata I luas lahan < 0,25 yang dibagi atas 4.950 ikat bedeng keuntungan yang diperoleh sebesar Rp.13.178.007 (transportasi 27.000), Rp13.169.007 (transportasi 36.000), dan Rp.13.155.007 (transportasi 50.000), kemudian keuntungan dari 5.600 ikat keuntungannya sebesar Rp.14.808.007 (transportasi 27.000), Rp14.799.007 (transportasi 36.000), dan 14.785.007 (transportasi 50.000).

Keuntungan pada strata II untuk luas lahan 0,26-0,50 yang di bagi atas 9.900 ikat keuntungan yang diperoleh sebesar Rp.27.005.007 (transportasi 27.000), keuntungan sebesar Rp.26.996.007 (transportasi 36.000), keuntungan sebesar Rp.26.982.007 (transportasi 50.000), kemudian untuk hasil produksi 10.400 ikat keuntungannya sebesar Rp.28.145.007 (transportasi 27.000), keuntungan sebesar Rp.28.136.007 (transportasi 36.000), keuntungan sebesar Rp.28.122.007 (transportasi 50.0000).

Keuntungan pada strata III dengan luas lahan > 0,51 ha terbagi atas 38.500 ikat keuntungan yang diperoleh sebesar Rp.148.739.007 (transportasi 27.000), keuntungan sebesar Rp.148.730.007 (transportasi 36.000), keuntungan Rp.148.716.007 (transportasi 50.000), kemudian untuk jumlah produksi 36.000 ikat, keuntungan yang diperoleh sebesar Rp.133.919.007 (transportasi 27.000), keuntungan sebesar Rp.133.910.007 (transportasi 36.000), keuntungan yang diperoleh sebesar Rp.133.896.007 (transportasi 50.000).

\begin{tabular}{|c|c|c|c|c|c|c|}
\hline Strata & $\begin{array}{l}\text { Luas Lahan } \\
\text { (Ha) }\end{array}$ & $\begin{array}{c}\text { Hasil } \\
\text { Produksi Ikat }\end{array}$ & $\begin{array}{c}\text { Biaya } \\
\text { Transportasi } \\
\text { (Rp) }\end{array}$ & $\begin{array}{l}\text { Penerimaan } \\
\text { (Rp) }\end{array}$ & $\begin{array}{c}\begin{array}{c}\text { Total } \\
\text { Biaya } \\
(\mathbf{R p})\end{array} \\
\end{array}$ & $\begin{array}{l}\text { Keuntungan } \\
\text { (Rp) }\end{array}$ \\
\hline \multirow[t]{5}{*}{ I } & $<0,25$ & 4950 & $\begin{array}{l}27.000 \\
36.000\end{array}$ & 24.750 .000 & $\begin{array}{l}11.571 .993 \\
11.580 .993\end{array}$ & $\begin{array}{l}13.178 .007 \\
13.169 .007\end{array}$ \\
\hline & & & 50.000 & & 11.594 .993 & 13.155.007 \\
\hline & & 5600 & 27.000 & 28.000 .000 & 13.191.993 & 14.808 .007 \\
\hline & & & 36.000 & & 13.200 .993 & 14.799 .007 \\
\hline & & & 50.000 & & 13.214 .993 & 14.785 .007 \\
\hline \multirow[t]{6}{*}{ II } & $0,26-0,50$ & 9900 & 27.000 & 49.500 .000 & 22.494 .993 & 27.005 .007 \\
\hline & & & 36.000 & & 22.503 .993 & 26.996 .007 \\
\hline & & & 50.0 & & 22.517 .993 & 26.982 .007 \\
\hline & & 10400 & 27.000 & 52.000 .000 & 23.854 .993 & 28.145 .007 \\
\hline & & & 36.000 & & 23.863 .993 & 28.136 .007 \\
\hline & & & 50.000 & & 23.877 .993 & 28.122 .007 \\
\hline \multirow[t]{6}{*}{ III } & $>0,51$ & 38500 & 27.000 & 192.500 .000 & 43.760 .993 & 148.739 .007 \\
\hline & & & 36. & & 43.769 & 148.730 .007 \\
\hline & & & 50.000 & & 43.783 .993 & 148.716 .007 \\
\hline & & 36000 & 27.000 & 180.000 .000 & 46.080 .993 & 133.919 .007 \\
\hline & & & 36.000 & & 46.089 .993 & 133.910 .007 \\
\hline & & & 50.000 & & 46.103 .993 & 133.896 .007 \\
\hline
\end{tabular}

\section{KESIMPULAN DAN SARAN}

\section{Kesimpulan}

Berdasarkan hasil analisis dan pembahasan mengenai Analisis Keuntungan Produksi Bawang daun petani di Desa Bongkudai Utara, dapat disimpulkan bahwa semakin banyak jumlah produksi (ikat) maka semakin tinggi penerimaan yang diperoleh petani. Jumlah Penerimaan petani bawang daun di Desa Bongkudai Utara Kecamatan Mooat yang lebih tinggi adalah pada strata III dengan luas lahan >0,51 yang terbagi atas 110 bedeng sebesar Rp.192.500.000 dan 120 bedeng sebesar 180.000 .000 , dengan demikian jumlah biaya yang dikeluarkan petani bawang daun yang lebih banyak adalah pada strata III untuk luas lahan > 0,51 yang terbagi atas 110 bedeng sebesar Rp.43.886.900 dan 120 bedeng sebesar Rp.46.206.900, sehingga keuntungan yang lebih tinggi yang diperoleh petani adalah strata III dengan luas lahan > 50 hektar yang dengan jumlah produksi 38.500 ikat dan 38.500 ikat sebesar Rp.148.739.007 (transportasi 27.000), Rp.148.730.007(transportasi 36.000), Rp.148.716.007 (50.000), dan untuk jumlah produksi 36.000 ikat keuntungannya sebesar Rp.133.919.007(transportasi 27.000), Rp. 133.910.007 (transportasi 36.000), Rp.133.896.007 (transportasi 50.000).

\section{Saran}

Berdasarkan hasil penelitian yang telah dilakukan penulis menyarankan untuk petani agar supaya lebih memanfaatkan luas lahan yang dimilki agar dapat menghasilkan jumlah produksi yang lebih tinggi sehingga pendapatan dan keuntungan meningkat. Untuk pemerintah agar dapat melaksanakan penyuluhan tentang teknik pengelolaan usahatani bawang daun terkait dengan usaha meningkatkan produksi.

\section{DAFTAR PUSTAKA}

Asmara R., Hanani N F. 2014. Strategi Peningkatan Daya Saing Komoditas Pertanian. Penerbit Gunung Samudera Mangliawan, Pakis. Malang.

Suratiyah K. 2009. Pengantar Ilmu Usahatani. Penerbit Penebar Swadaya. Jakarta. 